Mirosław Karwat

Uniwersytet Warszawski

\title{
Spirala przemocy w konfliktach społecznych
}

DOI: $10.19195 / 1643-0328.22 .9$

Słowa kluczowe: antagonizm, błędne koło, eskalacja, konflikt antagonistyczny, przemoc, eskalacja przemocy, spirala przemocy

\section{Wprowadzenie}

Jednym z fenomenów przemocy występującej w stosunkach politycznych jest wspólna pułapka negatywnej spontaniczności, w jaką wzajemnie wciągają się antagoniści w dowolnym konflikcie antagonistycznym. Wtedy działania wrogie i ich odwzajemnienie nie zamykają konfrontacji z określonym rezultatem, lecz uruchamiają żywiołowy proces eskalacji aktów agresji (także skrajnie irracjonalnych) i swoistej licytacji w próbach przebicia antagonisty natężeniem destrukcji. Wrogość ulega fiksacji - każda ze stron utwierdza się w postawie zaciekłości i w dążeniu do niepodzielnego zwycięstwa, choć coraz mniej realnego w warunkach wzajemnego klinczu. Ale ta niemożliwość zwycięstwa kompensowana jest negatywną licytacją $\mathrm{w}$ szkodach zadawanych stronie przeciwnej. A rezultatem kumulacji urazów, „rachunków krzywd” i postaw odwetowych staje się praktyczna niemożliwość przerwania powstałego błędnego koła wzajemnej i wspólnej destrukcji, tudzież autodestrukcji. Żywą ilustracją takiego fenomenu jest nieskończony i zgoła niemożliwy do rozwiązania konflikt izraelsko-palestyński ${ }^{1}$ czy konflikt w Irlandii Północnej. Ale ta sama prawidłowość dotyczy wielu innych, mniej znanych konfliktów $\mathrm{w}$ różnych regionach świata - terytorialnych, etnicznych, wyznaniowych.

W rozmaitych działaniach wojennych (nie tylko dosłownie zbrojnych) raz po raz można zaobserwować swoiste perpetuum mobile destrukcji i autodestrukcji, niepowstrzymaną eskalację przemocy i desperacką licytację siłą zniszczenia. Ideologiczną racjonalizacją (dorabianiem sensu do irracjonalnych odruchów, postaw zaślepienia w uporze i małostkowości) jest zwykle przekonanie o absolutnej własnej słuszności i powinności przeforsowania (za wszelką cenę) tego, co słuszne, ale i odruchy pospolitej mściwości.

${ }^{1}$ Por. na ten temat: A. Oz, Czarownik swojego plemienia. Eseje, Warszawa 2007; idem, Jak uleczyć fanatyka?, Warszawa 2010; M. Vargas Llosa, Izrael-Palestyna. Pokój czy święta wojna, Warszawa 2007. 
Paradoksalnie, postępowanie każdej ze stron jest „wodą na młyn” strony przeciwnej. Potwierdza się więc w tym wypadku trafność prakseologicznego pojęcia kooperacji negatywnej, w którym zakłada się, że wzajemne przeciwdziałanie, przeszkadzanie sobie i wyrządzanie szkód jest tak czy inaczej kooperacją (choć „negatywną”). Kooperacją, gdyż rywalizacja, walka lub wojna są splotem współzależnych dążeń i działań, a oponenci (rywale, przeciwnicy, wręcz wrogowie), paradoksalnie, nawzajem pomagają sobie w powodowaniu szkód - i po przeciwnej, i po własnej stronie ${ }^{2}$.

Czym wytłumaczyć fakt, że w wielu wojnach między państwami, wojnach domowych, konfliktach etnicznych i terytorialnych, wojnach i pogromach religijnych itp. konfrontacja i destrukcja trwa nie tyle „aż do końca, do zwycięstwa” (czyli do chwili osiągnięcia rzeczywistej przewagi jednej ze stron i korzyści kosztem pokonanego wroga), ile „bez końca”, z perspektywą wspólnej i wzajemnej zagłady? Dlaczego zagrożenie autodestrukcją nie powstrzymuje stron przed kontynuacją wojny, której wygrać żadna z nich nie może, a która coraz więcej kosztuje i coraz bardziej zagraża ich własnej egzystencji? Jakim „cudem” możliwe są - na poziomie zachowań zbiorowych i działania wielkich struktur - reakcje typu „na złość mamie odmrożę sobie uszy” czy „pies ogrodnika” (sam nie zjem, ale — choćbym miał zginąć — nie pozwolę zjeść innemu)? Co sprawia, że strony antagonistycznych konfliktów politycznych kierują się irracjonalną zasadą fiat iustitia et pereat mundus (sprawiedliwości - według moich wyobrażeń i kryteriów — musi stać się zadość, choćby świat miał sczeznąć)?

\section{Podłoże wspólnego uwikłania w walkę bez wyjścia}

Wbrew pozorom, pułapce takiej ulegają nie tylko ruchy fanatyczne, tendencje ekstremistyczne, ale potencjalnie każdy podmiot polityki, który uwikła się w tożsamościowo-godnościowo-prestiżowe (zamiast pragmatycznych) kryteria oceny rywalizacji, walki lub wojny ${ }^{3}$. Jeśli już sama w sobie konfrontacja ze stroną przeciwną (w warstwie emocjonalnej i symbolicznej, w oderwaniu od jej praktycznych celów i możliwych efektów realnych, wymiernych) staje się manifestacją własnej tożsamości, jeśli zwycięstwo (a w każdym razie zdolność do nieskończonej nieustępliwości) ma być sprawdzianem i potwierdzeniem własnej tożsamości i godności, a zarazem warunkiem zachowania respektu w otoczeniu i dowodem własnej wyższości, to szansa na uniknięcie, a przynajmniej na uregulowanie konfliktu (czy to w drodze porozumienia obustronnego, czy to $\mathrm{w}$ rezultacie mediacji) jest znikoma.

2 To paradoksalne pojęcie zawdzięczamy oczywiście Tadeuszowi Kotarbińskiemu. Zob. T. Kotarbiński, Abecadło praktyczności, Warszawa 1972; idem, Traktat o dobrej robocie, Warszawa 1975.

${ }^{3}$ Celną charakterystykę godnościowego podejścia do konfliktu i walki politycznej przedstawił swego czasu Andrzej Grzegorczyk - w komentarzu do wydarzeń lat 1980-1981 w Polsce. Zob. A. Grzegorczyk, Wszyscy chcemy być ważni i niezależni, [w:] Gwatt i perswazja. Antologia publicystyki z lat 1981-1983, red. J. Adamski, Warszawa 1983. 
Jednak podłoża takiej wspólnej pułapki należy szukać nie tylko i nie najpierw w aberracjach psychologicznych (emocjonalnych i poznawczych), lecz przede wszystkim w charakterze konfliktu i w układzie sił.

Konflikty społeczne i ściśle polityczne w sytuacji zdecydowanej i trwałej przewagi jednej ze stron zakończone są zwykle zwycięstwem (a więc triumfem i korzyścią) strony silniejszej, a porażką (degradacją i stratą) lub wręcz klęską (upokorzeniem i rozbrojeniem) strony słabszej. Choć rachunek korzyści i strat należy rozpatrywać raczej w kategoriach bilansu (wynik per saldo, z uwzględnieniem kosztów po obu stronach) niż jako „czysty zysk” i odpowiednio „wyłączną stratę".

Inaczej już jest w sytuacji względnej równowagi lub zmiennego układu sił. Wówczas konflikty miewają zarówno "dynamikę pozytywną" (kiedy przebieg wydarzeń i splot działań ewoluuje w kierunku rozwiązania problemu, a co najmniej „zawieszenia broni”, ewentualnie prowadzi do kompromisu i uregulowania stosunków między stronami sporu), jak i „dynamikę negatywną" (kiedy narastanie destrukcji jest odwrotnie proporcjonalne do jej efektów dla którejkolwiek ze stron). Dynamika pozytywna najczęściej ma miejsce w konfliktach nieantagonistycznych, natomiast negatywna - w tym skłonność do eskalacji przemocy - w konfliktach antagonistycznych (zob. dalej).

Mechanizm, który się wówczas ujawnia, doczekał się popularnego, a metaforycznego określenia: spirala przemocy. Następuje tu redukcja lub wręcz zanik samokontroli u każdej ze stron pod wpływem negatywnych emocji (zacietrzewienia) i przekroczenie bariery racjonalności w działaniach agresywnych i destrukcyjnych - aż do granic autodestrukcji.

Kluczem do zrozumienia tego mechanizmu są typowo metaforyczne, a jednak precyzyjne pojęcia: polaryzacja; fiksacja dążeń i postaw; błędne koło czy też „zaklęty krąg” (destrukcji i autodestrukcji); eskalacja (ciosów) i licytacja (zamachami, szkodami); dynamiczne sprzężenie zwrotne. Zwieńczeniem związku tych pojęć jest modelowe pojęcie „spirali”. W nim nacisk położony jest na dynamikę konfliktu (konfrontacji): każde następne stadium jest konsekwencją kumulacji skutków stadiów poprzednich, a zarazem wnosi swój wkład do tej kumulacji.

\section{Antagonizm i polaryzacja}

„Spirala przemocy” jest prawidłowością nie we wszelkich możliwych konfliktach, lecz jedynie w tych antagonistycznych.

Antagonistycznych - to znaczy jakich? Takich, że obiektywnie niemożliwe jest, a przynajmniej nie mieści się w wyobraźni stron konfrontacji, rozwiązanie sprzeczności interesów i przeciwieństwa dążeń przez porozumienie, kompromis lub przetarg, w ramach istniejących stosunków i wspólnie uznawanych reguł; jedyne zaś rozwiązanie, jakie się nasuwa, polega na przekreśleniu jakiejkolwiek wspólnoty i na usunięciu ze wspólnej przestrzeni albo na zniszczeniu lub w każdym razie na pognębieniu i podporządkowaniu drugiej strony. Pretendenci do tych samych dóbr nie są tu rywalami, konkurentami ani nawet przeciwnikami, którzy, rozgrywając ostrą walką, respektują nawzajem swoją 
tożsamość, godność i prawo do istnienia, lecz wrogami, dążącymi do eliminacji żywej przeszkody ${ }^{4}$. Wrogość ta może mieć wymiar obiektywny, związany z niepodzielnością lub niemożliwością wspólnego użytkowania pewnego dobra (co akcentuje się np. w teorii marksistowskiej czy w koncepcji Carla Schmitta), lub subiektywny, związany z obcością i przeciwstawnością kulturową, mentalną, z siłą urazów lub negatywnych uprzedzeń (jako nastawień apriorycznych i irracjonalnych) ${ }^{5}$.

Wiele innych konfliktów, nawet o dramatycznym i drastycznym początkowo przebiegu, można rozwiązać (i rzeczywiście są rozwiązywane, a przynajmniej zamrażane) w rezultacie wyczerpania sił obydwu stron, „ochłonięcia” uczestników, zwłaszcza ich spadkobierców, a w konsekwencji dzięki gotowości i umiejętności zastosowania procedur negocjacyjnych, sposobów wypracowywania kompromisu ${ }^{6}$.

Inaczej jest w konfliktach antagonistycznych, których przebieg jest zaprogramowany zgodnie z zasadą „kto kogo” (obezwładni i podporządkuje sobie lub wyeliminuje — tzn. zasymiluje, nawróci lub wypędzi albo zniszczy).

Konflikty antagonistyczne rozwijają się w sytuacji, gdy spór dotyczy albo dobra niepodzielnego, albo takiego, którego podział nie rozwiązuje ani problemów praktycznych, ani psychologicznych (np. prestiżowych), symbolicznych, albo deficytowego, którego zasoby są zbyt nikłe, aby jakikolwiek podział (a raczej przydział) zadowolił kogokolwiek lub zapobiegł poczuciu krzywdy po stronie pominiętych lub upośledzonych, albo wreszcie takiego, którego wspólne użytkowanie jest z takich czy innych względów niewykonalne, względnie przyczynia się do nasilenia wrogości i konfrontacji.

Do takich dóbr „wyłącznych” i niepodzielnych należą zwłaszcza: terytorium (w sporach i konfliktach między państwami - o granice, w antagonizmach plemiennych i etnicznych) oraz racja ideologiczna (np. w wojnach religijnych).

\section{Fiksacja roszczeń i wrogości}

Obiektywna lub nawet tylko subiektywnie wyobrażona i odczuwana niemożliwość pogodzenia interesów i roszczeń skonfliktowanych stron (wykluczająca - obiektywnie lub subiektywnie - bezpośredni kompromis lub np. mediację czy arbitraż) pociąga za sobą usztywnienie nastawień wyjściowych (co jest odwrotnością pragmatycznej elastyczności), a dotychczasowe starcia i przeżywane porażki, straty utrwalają skłonność do rewanżu, odwetu (nawet za wszelką cenę), do kompensowania własnych rozczarowań i upokorzeń choćby zastępczymi szkodami wyrządzonymi adwersarzom.

${ }^{4}$ Jakościowa różnica między statusem rywala, przeciwnika i wroga omawiana i uzasadniana jest w pracy: M. Karwat, Podstawy socjotechniki. Dla politologów, polityków i nie tylko, Warszawa 2014.

${ }_{5}$ Por. na ten temat: E. Karolczuk, O wrogu. Szkice filozoficzno-historyczne, Warszawa 2010; J. Ziółkowski, Wrogość w stosunkach politycznych. Modelowa analiza funkcjonalna, Warszawa 2013; idem, Wrogość jako paradoks demokracji, [w:] Antynomie i paradoksy współczesnej demokracji, red. M. Tobiasz, Warszawa 2016.

${ }^{6}$ Por. na ten temat: J. Rudniański, Kompromis i walka. Sprawność i etyka kooperacji pozytywnej i negatywnej w gęstym otoczeniu społecznym, Warszawa 1989; S. Bieleń, Negocjacje w stosunkach międzynarodowych, Warszawa 2013. 
Do takiej sytuacji właśnie odnosi się psychologiczna koncepcja fiksacji, której istotę przystępnie omówił Wiesław Łukaszewski:

Długa seria eksperymentów nad zachowaniem się człowieka w sytuacjach, gdy doznaje on niepowodzenia, dowiodła, że w pewnych warunkach miast racjonalnego poszukiwania wyjścia z sytuacji pojawiają się i uporczywie powtarzają stereotypowe reakcje nie prowadzące ani do osiągnięcia założonego celu, ani do uniknięcia niepowodzeń. Kolejne porażki nie tylko nie zmniejszają prawdopodobieństwa powtórzenia stereotypowej reakcji, ale przeciwnie - prawdopodobieństwo to zwiększają. Wyniki badań dowodzą także, iż w tym zakresie reakcje ludzi i zwierząt niewiele różnią się od siebie. Zdeterminowanie, brak refleksji, statyczne i stereotypowe ukierunkowanie aktywności - to zasadnicze cechy takiego zachowania się. Towarzyszy temu coś, co bez obawy nazwać można specyficzną ślepotą. Ludzie tracą zdolność dostrzegania informacji, które mogłyby im pomóc w rozwiązaniu zadania. Nie potrafią np. korzystać z podpowiedzi czy sugestii ułatwiających wyjście z sytuacji — podsuwanych im przez innych ludzi ${ }^{7}$.

Ta tendencja dotyczy nie tylko konfliktów interpersonalnych, których korelatem jest jednostkowa zawziętość i przeżywanie wszelkiego oporu w kategoriach czyjejś osobistej złośliwości, a własnego upokorzenia. Analogicznie przedstawia się ona w przypadku konfliktu między dwiema wspólnotami ludzkimi — na tle sprzeczności interesów, kolizji mentalności i poglądów, a jeszcze bardziej wtedy, gdy w grę wchodzą zarazem i sprzeczne interesy, i przeciwstawne wartości, i wspomniane już godnościowo-prestiżowe postrzeganie konfliktu.

$\mathrm{Na}$ ogół tego rodzaju irracjonalne usztywnienie zachowania się, jednokierunkowe zdeterminowanie aktywności, rozpatruje się jako następstwo napotkania trudnych do pokonania przeszkód, wyzwalających silne napięcia emocjonalne. Wydaje się to słuszne o tyle, o ile przyjmuje się, że w bardzo trudnych sytuacjach prawdopodobieństwo fiksacji jest szczególnie wysokie. Sytuacje złożone i trudne szczególnie łatwo ujawniają skrajne formy fiksacji, ale bynajmniej nie jest tak, jakoby fiksacja pojawiała się tylko w sytuacjach trudnych. W mniejszym nasileniu, w mniej ostrych formach można ją obserwować także w sytuacjach dalekich od ekstremalnych. Nawet w stosunkowo prostych sytuacjach można zobaczyć niekiedy fiksację występującą pod postacią dążenia do osiągnięcia jakiegoś celu za wszelką cenę, pod postacią przeświadczenia, że obrany cel jest jedynym celem wartym osiągania. Krótko mówiąc, zawsze wtedy, gdy człowiek nabiera przekonania, że albo osiągnie obrany przez siebie cel, albo nic nie jest warte jego zabiegów ${ }^{8}$.

W grze politycznej - o ile nie mamy do czynienia z daleko posuniętym, nawet bezideowym lub relatywistycznym, pragmatyzmem polityków przeciwnych stron - nader częstym zjawiskiem jest właśnie taki ideologiczny (aksjologiczny) maksymalizm, polegający na tym, że „nic nie jest ważne” (ani inne wartości zagrożone naszym uporem, ani koszty uporu) oprócz tej jednej wartości czy danego celu, którego realizacja jest bezwarunkową powinnością, spełnianą bez oglądania się na straty, szkody. Skrajną tego postacią jest oczywiście fanatyzm, zwłaszcza taki, który za szczyt cnoty uznaje gotowość do samopoświęcenia, autodestrukcji w imię wyznawanej świętości.

Człowiek spostrzega jeden tylko istotny cel przed sobą, tak dalece dlań istotny, że nabiera przekonania, iż musi go osiągnąć za wszelką cenę. Towarzyszy temu przeświadczenie o bardzo negatywnych skutkach ewentualnego nieosiągnięcia celu. Zaczyna powstawać zadziwiający zaiste mechanizm. Z jednej strony bowiem przesadna ocena wartościowości i doniosłości obranego celu przesądza o tym, że wszystko inne wydaje się mało wartościowe, mało ważne, mało potrzebne. $\mathrm{Z}$ drugiej strony, taki właśnie punkt widzenia

7 W. Łukaszewski, Szanse rozwoju osobowości, Warszawa 1984, s. 440-441.

8 Ibidem, s. 441. 
podtrzymuje, a nawet podwyższa i tak już wysoką ocenę doniosłości i wartościowości celu. Cel wyłączny, im bardziej jest subiektywnie doniosły i wartościowy, tym w miarę upływu czasu staje się ważniejszy i jeszcze bardziej wartościowy, a przewidywane skutki nieosiągnięcia celu wydają się tym groźniejsze i tragiczne, wręcz zagrażające utratą sensu własnej egzystencji ${ }^{9}$.

Im wyższa wartość uświęconego celu lub dobra stającego się fetyszem, tym wyższą cenę jesteśmy gotowi zapłacić za jego osiągnięcie. Zarazem jednak w kalkulacji kosztów - o ile takiej dokonujemy, o ile nie działamy zupełnie emocjonalnie - bagatelizujemy, zaniżamy wartość tego, co poświęcamy na ołtarzu jedynego celu, dobra, i tego, co marnotrawimy „ubocznie”. Natomiast demonizujemy ewentualną porażkę; nieosiągnięcie zakładanej satysfakcji lub wymiernej korzyści uznajemy za synonim zguby. W efekcie przyjmujemy w postępowaniu zasadę „albo wszystko, albo... nicość”.

O ile jest to cel niezbyt złożony, np. konkretny czy konsumpcyjny, i niezbyt trudny do osiągnięcia, konsekwencje opisanego wyżej mechanizmu nie są ani zbyt poważne, ani zbyt rozległe. Jeżeli jednak w grę wchodzi trudny do osiągnięcia i bardzo złożony cel, sytuacja staje się nadzwyczaj skomplikowana.

Wyłączność celu i wielka doniosłość sprzyjają przecenianiu szans na jego osiągnięcie. W fazie początkowej realizacji celu istnieje zatem nie tylko tendencja do antycypowania sukcesu, ale wręcz przesadna wiara w możliwość jego osiągnięcia. Motywacja działania jest więc w punkcie wyjścia bardzo silna. W miarę wszakże kontynuacji działań szanse osiągnięcia wyniku - obiektywnie rzecz biorąc - nie rosną, lecz maleją. W takiej sytuacji należałoby oczekiwać albo wzmożenia aktywności, albo przewartościowania celu, albo modyfikacji metod i lepszego dostosowania ich do specyfiki celu. Ze względu na wyłączność celu i jego znaczną doniosłość dla jednostki najbardziej prawdopodobne jest to pierwsze. W miarę kontynuacji działań i kolejnych doznawanych niepowodzeń człowiek wzmaga aktywność (nie zmieniając bynajmniej jej struktury) i jeszcze bardziej koncentruje się na postawionym celu. Nasila się swoista ślepota na inne możliwe cele, na inne okazje czy metody. Pojawia się całkowita odporność na działanie atrakcyjnych pokus, a wszystko to $\mathrm{w}$ imię przyjętego celu, który z czasem nabiera charakteru wręcz sakralnego ${ }^{10}$.

Na tym więc etapie fiksacja celu i dążeń, zamiarów, roszczeń podmiotu pociąga za sobą myślenie życzeniowe (wishful thinking), którego korelatem jest z kolei woluntaryzm (wszystko wydaje się możliwe i zależne jedynie od natężenia woli i wysiłków, od zdecydowania, determinacji, niezmiennej konsekwencji). Podmiot, który uległ takiej tendencji, zaczyna działać jak automat powtarzający wciąż ten sam schemat działania. Jego działanie przypomina zdartą płytę, która się zacina i której igła nieskończenie powraca $\mathrm{w}$ to samo miejsce $\mathrm{z}$ tym samym taktem.

Pojawia się, wreszcie, nowy element tej złożonej sytuacji. Człowiek zaczyna nabierać przekonania, że jeżeli nie jest w stanie osiągnąć wybranego przez siebie celu, to on sam nic nie jest wart. Cel działania nabiera tedy znaczenia autoprestiżowego. Staje się po prostu kryterium - niekiedy jedynym - własnej wartości. Koncentracji na celu zaczyna towarzyszyć, a potem ją zastępować, koncentracja na własnej wartości, a ściślej - na obronie własnej wartości ${ }^{11}$.

Powiada się wtedy, nieściśle, że „honor nie pozwala” zrezygnować, wycofać się, ustąpić, szukać innego rozwiązania problemu. Honor błędnie rozumiany — nie jako wierność własnym zasadom i zobowiązaniom, lecz jako synonim urażonej dumy, poczucia nieomylności, obawy przed degradacją (kto nie zwyciężył, ten przegrał, a kto przegrał, ten został poniżony).

9 Ibidem, s. 441-442.

10 Ibidem, s. 442.

11 Ibidem, s. 442-443. 
Nietrudno przewidzieć dalszy ciąg tego błędnego koła. Jeszcze bardziej fanatyczne działanie, jeszcze większa ślepota, jeszcze większe przerażenie na myśl, że istnieje możliwość nieosiągnięcia celu. Wzmożona emocjonalność powoduje zakłócenia w funkcjonowaniu psychicznym, co dodatkowo powiększa i tak wysokie prawdopodobieństwo porażki. Człowiek znalazł się w ślepej uliczce, z której na dobrą sprawę nie znajdzie wyjścia, jeśli nie wystąpią bardzo silne oddziaływania zewnętrzne, tak silne, że zdołają człowieka skłonić do przebudowania hierarchii wartości, a nie jest to - jak wiadomo - sprawa bynajmniej prosta. Jeśli coś takiego się nie zdarzy, oczekiwać można zupełnie paradoksalnego efektu. Upragniony cel miast tracić - zyskuje na wartości i doniosłości. Metody działania, miast stawać się elastycznymi, przekształcają się w powtarzalne stereotypy. Człowiek, zamiast się rozwijać, zamyka się w kręgu ideè fixe. Świat kurczy się do ,ja” i celu działania, a cała reszta pozbawiona jest wartości, budzi lęk lub wstręt ${ }^{12}$.

Można by rzec, iż człowiek w takiej sytuacji i w takim stanie psychicznym nie tylko staje się niezdolny do zachowania lub odzyskania dystansu do sprawy i własnych czynów, ale wręcz staje się nietolerancyjny wobec samego siebie. Nie dopuszcza lub tłumi i nie wybacza sobie własnych wątpliwości, głosów rozsądku, przebłysków myślenia alternatywnego.

A co się dzieje wtedy, gdy fiksacji ulega działanie zespołowe, grupowe, zbiorowe? Wówczas ci, którzy mienią się (samym sobie, lecz z roszczeniami, by narzucić własne oceny i zamiary innym) niezłomnymi, chwalebnie wiernymi, widzą we wszelkich dysonansach we własnych szeregach ( $w$ niedostatecznej gorliwości, w sygnałach gotowości do ustępstw, czy choćby honorowego wycofania się z dążeń nierealnych) defetyzm, a nawet tchórzostwo i zdradę. I przeciw swym „podejrzanym” współtowarzyszom kierują impet wrogości nawet nie mniejszy niż przeciw formalnym, zewnętrznym wrogom. Odpowiednikiem indywidualnej fiksacji na poziomie zbiorowym staje się zatem „syndrom oblężonej twierdzy”13.

\section{Demoralizacja i dehumanizacja w konfliktach destrukcyjnych}

Fiksacja uprzedzeń i urazów towarzysząca „afektywnej polaryzacji” w konfliktach społecznych powoduje - dostrzeganą raczej przez postronnych niż przez samych uczestników - demoralizację walczących po jednej i po drugiej stronie, a w ślad za tym idzie skłonność do skrajnej nawet dehumanizacji przeciwnika ${ }^{14}$. Zwrócił na to uwagę Janusz Reykowski w swym komentarzu do psychologii konfliktów grupowych:

jeżeli w normalnych sytuacjach, w tym także w trakcie konfliktów niedestruktywnych, każdy z nas jest mniej lub bardziej zdolny do tego, by zrozumieć cudze położenie, inne racje i cudze wartości, to w sytuacji konfliktu destruktywnego zdolność ta zanika. Racji przeciwników się nie rozumie, bo oni — jak się wtedy sądzi - po prostu ich nie mają. Przeciwnicy to nędzne istoty, bądź przekupione przez obcych, bądź omamione przez fałszywych proroków. [...] W rzeczy samej są wcieleniem zła ${ }^{15}$.

12 Ibidem, s. 443.

13 Model tego zjawiska zob. w artykułach: J. Ziółkowski, Syndrom oblężonej twierdzy jako mechanizm socjotechniczny, [w:] Socjotechnika lęku w polityce, red. F. Pierzchalski, J. Golinowski, Bydgoszcz 2016; idem, Zarządzanie syndromem oblężonej twierdzy w demokracji liberalnej, [w:] Wplyw i władza w systemie demokratycznym, Warszawa 2016 (= „Studia Politologiczne” 41).

14 Formy tej dehumanizacji wroga - w kontekście walki politycznej w III RP, a w nawiązaniu do koncepcji Carla Schmitta - przedstawione są w artykule: J. Rokita, Pięć wizji wroga, „Horyzonty polityki” 6, 2015, nr 15.

${ }^{15}$ J. Reykowski, Logika walki, Warszawa 1984, s. 62, 63. 
W takich konfliktach triumfuje manichejska dychotomia (nasza walka $\mathrm{z}$ nimi to po prostu walka dobra ze złem) oraz „moralność Kalego”, podwójna miara, czyli hipokryzja ${ }^{16}$.

$\mathrm{Z}$ tym wiąże się ograniczenie zakresu zastosowania zasad moralnych i gotowości do współczucia. Publiczne poniżenie kogoś, kto się nam przeciwstawił, zasługuje na aplauz, natomiast jeżeli to samo spotyka kogoś, kto jest po naszej stronie, wzbudza to święte oburzenie.

Specyficznej interpretacji podlegają normy moralne: słuszne i sprawiedliwe jest to, co głosi i czyni nasza strona. To, co robi przeciwnik, uważa się za nic więcej niż tylko złośliwe przeszkadzanie ${ }^{17}$.

Cokolwiek uczynimy w naszym interesie i w celu potwierdzenia naszych racji, a na szkodę przeciwników, to będzie słuszne, a co najmniej zrozumiałe i usprawiedliwione. Empatia nie jest tu w cenie: cokolwiek uczyni oponent wbrew naszej woli i z naszą stratą, będzie to dla nas uporem iświństwem, nie zaśdziałaniem podyktowanymjego własnym interesem i przekonaniem. Ta moralizatorska jednostronność pozwala nam nie liczyć się ani z racjami przeciwnika, ani z elementarnymi warunkami jego godności i bezpieczeństwa: konflikt destrukcyjny prowadzi do dehumanizacji przeciwnika, a więc pozbawia go cech ludzkich: nie jest on już kimś takim jak my i dlatego możemy zwalczać go bezwzględnie. Wyobrażenie uwięzienia go, zadania mu ran czy postawienia pod szubienicę zostaje usankcjonowane, dotyczy bowiem „obcych”, „innych” - nie naszych. Towarzyszy temu tendencja do deprecjacji przeciwnika tak pod względem moralnym, jak i umysłowym $^{18}$.

Nasz przeciwnik - co „oczywiste” — jest (do wyboru) draniem, złoczyńcą, przestępcą, krętaczem, głupcem, zboczeńcem, obrzydliwcem; a kwalifikacje wrogiej wspólnoty są dość podobne do tych jednostkowych, osobistych ${ }^{19}$. Z tego też powodu nie wchodzą $\mathrm{w}$ grę pochodzące $\mathrm{z}$ zewnątrz próby zażegnania konfliktu, pojednania lub uzgodnienia wzajemnych ustępstw:

nie uznajemy stanowisk pośrednich i kompromisów. Trudno nam uwierzyć w dobrą wolę ludzi starających się znaleźć sposoby porozumienia, zażegnania konfliktu. Ich cele wydają się podejrzane: albo w sposób zawoalowany służą oni naszemu przeciwnikowi, albo też usiłują udawać neutralność, ponieważ nie wiedzą, kto zwycięży, a nie chcieliby nikomu się narazić.

Jeżeli jednak wierzymy niezachwianie $\mathrm{w}$ dobre intencje tych ludzi, to równocześnie podejrzewamy ich o naiwność. Ci ludzie kompromisu czy porozumienia mają, naszym zdaniem, głowę w obłokach, nie widzą realnej brutalności, podstępności i bezwzględności naszego przeciwnika. Łudzą się co do niego. Prędzej czy później przekonają się, kim jest naprawdę. Tak jak Chamberlain przekonał się, kim naprawdę był Hitler ${ }^{20}$.

Rezultatem takiego zapętlenia zarówno w percepcji strony przeciwnej, jak i w emocjonalnych reakcjach na jego działania jest eskalacja konfliktu, a więc - jak podpowiada nam etymologia (wł. scala; fr. escale - schody, drabina; escalade - wchodzenie po drabinie, na coraz wyższy szczebel) - wzmaganie, potęgowanie oddziaływań wrogich na coraz to wyższym poziomie.

16 Charakterystykę hipokryzji zawierają prace: D. Runciman, Political Hipocrisy. The Mask of Power, from Hobbes to Orwell and Beyond, Princeton 2008; M. Karwat, Akredytacja w życiu społecznym i politycznym, Warszawa 2009, rozdział VII. Hipokryzja, czyli dwulicowość.

17 J. Reykowski, op. cit., s. 63.

18 Ibidem, s. 64.

19 Zob. na ten temat: M. Karwat, O złośliwej dyskredytacji. Manipulowanie wizerunkiem polityka, Warszawa 2006.

20 J. Reykowski, op. cit., s. 64-65. 


\section{Eskalacja działań destrukcyjnych}

Termin „eskalacja” na dobre zagościł w analizach konfliktów zbrojnych, a nawet tylko dyplomatycznych (przejawem tego jest wielofazowy mechanizm retorsji i ich odwzajemniania), ale znajduje zastosowanie do diagnozy jakichkolwiek konfliktów, także interpersonalnych.

Jest to takie zachowanie, które prowadzi do uruchomienia całej nagromadzonej frustracji poznawczej i emocjonalnej oraz przyczynia się do dalszego jej wzrostu. Eskalacji towarzyszy polaryzacja - zwiększenie i wyjaskrawienie konfliktu, zwiększenie wyrazistości i blokowanie porozumienia ${ }^{21}$.

Polaryzacja oznacza rozpatrywanie sytuacji w kategoriach absolutnego przeciwstawienia i rozdzielenia stron - jako dwóch biegunów, które nie mogą mieć żadnej styczności ani nawet wspólnego buforu. Nie chcą mieć one nic wspólnego, nie chcą uznawać niczego, nawet jakichś dóbr lub wartości i zasad nadrzędnych, co mogłoby je połączyć. Dwa przeciwstawne bieguny rozmieszczone są na antypodach, a pomiędzy sobą nie tolerują podmiotów neutralnych; postronni zmuszani są do opowiedzenia się po jednej ze stron. Zantagonizowane strony zachowują się więc tak, jak gdyby nic innego poza nimi nie istniało, a w każdym razie się nie liczyło. Dlatego rozwija się pomiędzy nimi wymiana ciosów na zasadzie licytacji (kto uderzy mocniej, kto przebije cios przeciwnika).

Przy czym ważne jest tutaj, czy mamy do czynienia ze spontaniczną, czy też ze strategiczną reakcją eskalacyjną.

Spontaniczne zachowanie eskalacyjne najczęściej prowadzi do wyolbrzymiania konfliktu, strony mają tendencję do łączenia konfliktów dotyczących faktów z tymi, które dotyczą zagrożenia samooceny. [...] Spontaniczne zachowanie eskalacyjne kończy się najczęściej ograniczeniem kontaktów, konflikt pozostaje nierozwiązany ${ }^{22}$.

Cóż, tendencją dominującą w konfliktach społecznych i makropolitycznych jest „afektywna polaryzacja". Wtedy strony konfliktu tracą dystans do sytuacji i do własnych emocji, ulegają własnym namiętnościom, co prowadzi do ograniczenia samokontroli, do kumulacji skłonności irracjonalnych. Racjonalne zachowania w konfliktach antagonistycznych i destrukcyjnych wiążą się nie tyle z trzeźwą i realistyczną analizą podłoża konfliktu, zrozumieniem możliwości jego rozwiązania, dostrzeżeniem własnej stronniczości i tendencyjności jako przeszkody w rozwiązaniu problemu, ile z pragmatycznymi sposobami rozgrywania tego konfliktu w kierunku zgodnym z własnymi nastawieniami i kalkulacjami:

Częstym sposobem eskalacji strategicznej jest rozszerzanie bądź zmiana przedmiotu konfliktu. Polega to na tym, że strona eskalująca „dokłada” do podstawowego przedmiotu konfliktu dodatkowe, pogłębiające konflikt lub pozwalające zastąpić dotychczasowy tematami zastępczymi ${ }^{23}$.

Warunkiem niesiłowego, lecz polubownego rozwiązania konfliktu jest oczywiście do bra wola po obu stronach. Trudno jednak na nią liczyć wtedy, gdy nastąpiła eskalacja konfliktu, licytacja w atakach, która potęguje urazy i stymuluje żądzę „odegrania się”, „od-

${ }^{21}$ S. Chełpa, T. Witkowski, Psychologia konfliktów. Praktyka radzenia sobie ze sporami, Wrocław 1999, s. 126.

22 Ibidem.

23 Ibidem, s. 127-128. 
dania z nawiązką", gdy zamiast rozsądku, analizy szans sukcesu postępowaniem stron rządzi „rachunek krzywd”. Tym bardziej, że gotowość do aktów dobrej woli nie jest czymś, co jesteśmy skłonni zaryzykować (z niebezpieczeństwem przeliczenia się), lecz czymś uzależnionym od... minimalnego zaufania do adwersarza (że tego aktu dobrej woli nie nadużyje).

Ścisły związek stopnia dynamiki ze stopniem wzajemnego zaufania występuje zresztą nie tylko w sytuacji kompromisu; szczególnie wyraźnie widoczny jest on walce, gdzie przy niemal całkowitym braku jakiegokolwiek kodeksu etycznego walki (istnieje on co prawda deklaratywnie) stopień obustronnego zaufania rzeczywistego jest niemal zerowy. Wtedy też obserwujemy najwyższy stopień dynamiki. Jest to kwestia oczywista: jeśli brak nawet elementarnego zaufania do kontr-partnera, który nie respektuje żadnych norm, przepisów ani deklaracji, to konieczny jest maksymalny wysiłek — odzwierciedlający się w bardzo intensywnych działaniach - aby zabezpieczyć się przed wszelkimi możliwymi niespodziankami ${ }^{24}$.

Wymogiem własnego bezpieczeństwa jest wtedy demonstracja siły, a choćby i pozorowanie, wyolbrzymianie tej siły, nie zaś odsłanianie się, ujawnianie jakiejkolwiek słabości - a za przejaw osłabienia może być uznana gotowość do rozmów, nawet tylko o zawieszeniu broni. Konfliktom destrukcyjnym i antagonistycznym towarzyszy zazwyczaj pułapka społeczna polegająca na tym, że obustronne i równoczesne sygnały opamiętania i samoograniczenia są niemal niemożliwe i psychologicznie, i technicznie, te jednostronne są zaś potencjalnie niebezpieczne dla inicjatora. Łatwiej zdobędzie się na nie podmiot faktycznie, choć jeszcze nie formalnie pokonany i wyczerpany, niż podmiot zachowujący równorzędność wobec przeciwnika, gdyż ten ma jeszcze coś do stracenia, ryzykuje utratę równowagi z powodu wykorzystania jego dobrej woli.

Współczesny wyścig zbrojeń stanowi jedną z wielu ilustracji sformułowanej wyżej prawidłowości czy reguły natury prakseologicznej, którą można również wyrazić $\mathrm{w}$ formie imperatywu: im mniej masz zaufania czy to do swojego sojusznika $w$ kompromisie, czy do swojego kontr-partnera $w$ walce, tym bardziej intensyfikuj swoje działania, aby być przygotowanym na wszelkiego typu możliwe i nie zawsze przewidywalne posunięcia ${ }^{25}$.

To rozumowanie analogiczne do klasycznej maksymy si vis pacem, para bellum.

Podsumujmy. Fiksacja wrogości i uporu, eskalacja emocji, licytacja w atakach i urazach (kto bardziej ucierpiał, kto bardziej zasłużył na karę, zemstę) zamyka obie strony konfliktu w błędnym kole niemożności wygrania, a zarazem niemożliwości wyrwania się z nieskończonej i nierozstrzygalnej walki, wojny.

\section{Błędne koło — dodatnie sprzężenie zwrotne}

Przypomnijmy w tym miejscu sens metaforycznego określenia „błędne koło” (lub podobnego: „zaklęty krąg”). Określenie to (circulus viciosus) znane jest zarówno z typologii błędów w definiowaniu terminów (błędne koło bezpośrednie lub pośrednie w definicjach), jak i z prakseologicznej analizy działań uwikłanych w niemożliwość przerwania powtarzalnych sytuacji i efektów. W terminologii cybernetycznej mechanizm takiej powtarzalności i/lub utrwalenia związku między dwoma zjawiskami nazywany jest sprzę-

\footnotetext{
24 J. Rudniański, op. cit., s. 252.

25 Ibidem.
} 
żeniem zwrotnym ${ }^{26}$. Oczywiście, nie każde sprzężenie zwrotne jest „błędnym kołem", ale każde błędne koło jest sprzężeniem zwrotnym.

Obrazowo ukazuje to analiza „nerwicowego błędnego koła”:

Sytuacja przypomina psa gryzącego swój ogon. Im silniej pies gryzie swój ogon, tym więcej go boli, tym bardziej jest poirytowany i jeszcze silniej gryzie. Jest to przykład dodatniego sprzężenia zwrotnego. W ujemnym sprzężeniu zwrotnym jego wzrost wywołuje spadek ilości sygnałów wysyłanych przez układ. Stabilność układu jest w ten sposób zachowana. (Na przykład w termostacie wzrost temperatury ponad wyznaczoną normę powoduje spadek w wytwarzaniu ciepła). W dodatnim sprzężeniu zwrotnym jest odwrotnie - jego wzrost powoduje wzrost sygnałów wysyłanych przez układ. (Wzrost temperatury w termostacie zamiast zmniejszać, zwiększyłby ilość wytwarzanego ciepła. W przypadku psa sprzężeniem zwrotnym są bodźce bólowe biegnące od gryzionego ogona, które wywołują jeszcze silniejsze gryzienie). Układ o dodatnim sprzężeniu zwrotnym jest układem niestabilnym, dążącym do autodestrukcji ${ }^{27}$.

Takim układem $\mathrm{z}$ tendencją do autodestrukcji jest właśnie konflikt antagonistyczny między stronami o wyrównanych siłach i porównywalnej determinacji, niezdolnymi ani do wyraźnego jednostronnego rozstrzygnięcia, ani do przerwania jałowej konfrontacji i licytacji.

Przykłady „błędnego koła” można znaleźć nie tylko w przypadku nerwic, lecz też w innych zaburzeniach psychicznych, a także w medycynie somatycznej. Na przykład schizofrenik, odczuwający lęk przed ludźmi, odsuwa się od otoczenia, coraz bardziej zamyka się w swoim świecie, wskutek czego coraz trudniej mu do ludzi się zbliżyć, coraz większy lęk przed nimi czuje. Zapalenie nerek łączy się zwykle z anemią, która z kolei jest przyczyną gorszego utlenienia tkanek i zmniejszenia odporności, co z kolei ujemnie wpływa na pierwotne schorzenie itp. ${ }^{28}$

O takim rozwoju współzależności między dwoma zjawiskami powiada się — w tejże cybernetycznej terminologii - iżjest to dy na miczne sprzężenie zwrotne - w odróżnieniu od statycznego, kiedy obustronna (współ)zależność zjawisk ma charakter jednorazowy i niejako zamknięty („w tę i z powrotem, i na tym koniec”) lub cykliczny (powtarzająca się reprodukcja stale tego samego stanu, związku, stanu rzeczy). Dynamiczne sprzężenie zwrotne to reprodukcja wprawdzie tej samej zależności, ale w coraz to nowszych warunkach, w większej skali, na coraz wyższych poziomach funkcjonowania współzależnych obiektów. I w rzeczy samej, eskalacja aktów wrogości nie jest prostą powtórką takich samych działań, lecz potwierdzaniem i pogłębianiem tej wrogości kolejnymi, bardziej złożonymi działaniami i szkodami o skutkach dalej idących niż działania wcześniejsze.

W ten sposób błędne koło okazuje się... spiralą.

\section{Schemat spirali}

Metafora spirali powstała nieprzypadkowo. Uzasadnione są skojarzenia i porównania dynamiki zachowań ludzkich lub zmian społecznych ze strukturą takich zjawisk przyrodniczych, jak wiry wodne, trąba powietrzna (mechanizm „wciągania”), ale i takich

\footnotetext{
26 Zob. M. Mazur, Cybernetyka i charakter, Warszawa 1976, rozdział 5. Sprzężenie.

27 A. Kępiński, Psychopatologia nerwic, Warszawa 1986, s. 176-177.

28 Ibidem, s. 177.
} 
prostych przyrządów jak choćby korkociąg. Choć takiej nazwy zwykle się nie używa w danym kontekście, to schemat spirali znakomicie pasuje do dynamicznej współzależności między stanem potrzeb społecznych, ich zaspokajaniem i ciągłym nienadążaniem zasobów oraz stosunków podziału za nieustannym wzrostem potrzeb (m.in. na zasadzie „apetyt rośnie w miarę jedzenia”; zaspokojenie potrzeby rodzi nowe potrzeby). Podobny mechanizm odnosi się do tzw. wyścigu konsumpcyjnego. Swoista „spirala konsumpcji” polega na tym, że konsumpcja pewnych dóbr nie tylko nie zaspokaja potrzeb, choć tego oczekiwano, lecz wzbudza nowe potrzeby i aspiracje konsumpcyjne, choć nieraz nie o charakterze praktycznym, użytkowym, lecz prestiżowym. Wreszcie, schemat spirali w pełni odnosi się do postępującego we współczesnej cywilizacji uzależnienia człowieka od źródeł energii i urządzeń technicznych: im bardziej skomplikowane i finezyjne urządzenia, tym większa bezradność użytkowników w sytuacji ich braku lub awarii.

Znanym modelem teoretycznym jest koncepcja „spirali milczenia” sformułowana w badaniach nad funkcjonowaniem opinii publicznej:

Teoria spirali milczenia zakłada, że społeczeństwo - nie tylko grupy, które się znają - grozi izolacją i odrzuceniem jednostek, które sprzeciwiają się porozumieniu, i że z drugiej strony jednostki mają najczęściej nieświadomą, prawdopodobnie zakorzenioną genetycznie obawę przed izolacją. Ta obawa skłania do ciągłego upewniania się, jakie opinie i zachowania aprobuje się lub potępia w otoczeniu oraz które opinie i zachowania się nasilają, a które słabną. Teoria mówi o zmyśle quasi-statystycznym, który pozwala dokonywać takich szacunków. Wynik tej oceny wpływa na wypowiedzi i zachowania. Jeśli ludzie sądzą, że są w zgodzie z porozumieniem opinii publicznej, bez wahania uczestniczą w rozmowach prywatnych i publicznych oraz ujawniają swoje przekonania, na przykład przez odznaki lub nalepki, ale również przez ubiór i inne publicznie widoczne symbole. Jeśli sądzą, że są w mniejszości, stają się ostrożni i milczący, nasilając tym samym publiczne wrażenie słabości tej opcji, aż zmniejszy się ona do niewielkiego twardego jądra, które pozostaje przy dawnych wartościach, lub aż dana opinia stanie się tabu ${ }^{29}$.

Otóż, w destrukcyjnych konfliktach antagonistycznych następuje taka autotelizacja przemocy (fizycznej lub psychicznej i rytualno-symbolicznej), która eskalacji działań, licytacji ataków i kumulacji negatywnych emocji, od jakiej nie ma odwrotu, nadaje cechy spirali agresji i przemocy.

Dosadnie ukazał to Wolfgang Sofsky w swoich rozważaniach o wielopiętrowej akceleracji drastycznych działań w konfliktach, w procesach walki, wojny.

\section{Perpetuum mobile walki}

Nawet wtedy, gdy powód był błahy, a cel mało znaczący, starcie wywołuje wrogość. Pierwszy zadany cios prowokuje kontruderzenie, pierwszy ranny - chęć odwetu, zabici wołają o zemstę. Opór wzmaga użycie siły, nacisk potęguje represje. Przemoc, zemsta, wściekłość i nienawiść - jedno wywołuje drugie. A te wzajemne emocjonalne reakcje przybierają na sile wraz z intensywnością konfrontacji. Im bardziej wzmaga się opór, tym potężniejsze uderzenie, im więcej przemocy w obronie, powstrzymującej przemoc ataku, tym wścieklejsza agresja. Pohamowanie posunięć strony atakującej pozbawia napastnika hamulców — tryb samozachowawczy przeradza się w namiętność wrogości. Furia walki każe zapomnieć o jej celu, pole walki zasłane jest nienawiścią, wściekłością i strachem. Im walka bardziej zażarta, tym bardziej absorbuje wal-

29 E. Noelle-Neumann, Spirala milczenia. Opinia publiczna - nasza skóra społeczna, Poznań 2004, s. 227. 
czących. Tak oto wojna tworzy wojownika, a walka - wroga. Sama rozpętuje siłę napędową, którą ją niesie i posuwa naprzód. Antagonizm zaszedł zbyt daleko. Przeciwnik staje się śmiertelnym wrogiem, instynkt samozachowawczy wyparty zostaje przez niezłomną wolę zadawania ran, zabijania ${ }^{30}$.

Słowem, następuje wspomniana już fiksacja - aż do takiego paradoksu, że nawet święty cel walki staje się nieważny, ważna jest już tylko walka. Pożądane jest nie tyle zwycięstwo i jakaś korzyść w jego wyniku, ile sama w sobie odpowiedź na ciosy wroga. A przebieg wydarzeń ucieleśnia schemat sprzężenia zwrotnego.

Wprawdzie pod wpływem nieefektywności tych coraz bardziej zaciętych odwzajemnień destrukcji nie może nie pojawić się myśl o zaprzestaniu walki, ale silniejsze od przebłysków rozsądku okazują się fiksacje zniszczenia.

Całkiem inaczej przebiega końcowa faza walki, jeśli przeciwnicy zmagają się ze sobą, mimo iż żaden z nich nie może już niczego zdobyć. Moment kryzysu mają za sobą, poniesione szkody są ogromne, łup uległ zniszczeniu, własne straty są niewiarygodnie duże, a mimo to zażartość nie pozwala im odpuścić wroga, ani też wycofać się. Walka staje się bezsensowną szarpaniną, bez widoków na sukces, zamienia się w przemoc absolutną. Nieuchronnie prowadzi do samounicestwienia. Nienawiść i wrogość nie pozwalają dojść do głosu rozsądkowi, zanika racjonalność trybu samozachowawczego. To tak, jakby wahadło walki poruszało się bez końca ${ }^{31}$.

Resztka sił (zresztą, na wyczerpaniu) nie służy wtedy do przetrwania dzięki przerwaniu zmagań, lecz wyłącznie do tego, aby wróg nie pomyślał, że już nie mamy sił, aby nie zachęcić go do próby „dobicia” i by ewentualnie doczekać, aż on pierwszy „padnie”.

Rozczarowanie brakiem sukcesu, pomyłką przeradza się w ślepą furię. Walka toczy się dalej, bo zaangażowanie w nią było bezsensowne. Wściekłość spowodowana daremnością poczynań nie zawaha się przed żadnym ryzykiem. Spycha na drugi plan strach i rozpacz, które w normalnych warunkach wiodą do opamiętania, choćby to miało być opamiętanie przez rezygnację. Jest to wściekłość niepohamowana, wściekłość na wroga i na siebie samego. Uruchamia ona ostatnie rezerwy i rzuca je do walki. Taka ślepa wola walki nie ma nic wspólnego z odwagą, która rozważa szanse i ryzyko. Jej celem jest totalne niszczenie. Ta wściekłość stanowi siłę napędową ofiarności. Wydaje się nie mieć znaczenia, czy dotknie ona przeciwnika, czy też samego atakującego. I tak na końcu padną wszyscy. Chaos przemocy nie pozostawia po sobie agonii, lecz spustoszenie ${ }^{32}$.

To kolejny paradoks: podświadoma wściekłość na samego siebie (do której jednak nie można się przyznać, jak nie można się przyznać do własnego błędu i własnej winy w swoich kłopotach, stratach) znajduje ujście w jeszcze większej wściekłości, nienawiści do wroga, którego nie udało się pokonać, a nic nie wskazuje na taką możliwość w następnym etapie. Atakujemy tym wścieklej, im mniej wierzymy, że to przyniesie zwycięstwo. To abstrakcyjne uogólnienie, ale z konkretnych przykładów wystarczy tu przywołać desperacki styl wojny totalnej nazistów w okresie poprzedzającym ich nieuchronną i oczywistą klęskę.

Agonia i chaos to konstelacje równowagi. Nie ma zwycięzców, są tylko przegrani. Strona skazana na przegraną walczy nadal. Odmowa kapitulacji może mieć kilka przyczyn. Pokonany nie chce się dostać żywy w ręce wroga, gdyż obawia się jego okrucieństwa. Przywódcy i towarzysze broni nakładają na poddających się kary, jak za tchórzostwo i dezercję, i zmuszają ich do dalszej walki, aż dojdzie do wspólnej zagłady ${ }^{33}$.

\footnotetext{
30 W. Sofsky, Traktat o przemocy, Wrocław 1999, s. 144.

31 Ibidem, s. 150-151.

32 Ibidem, s. 151.

33 Ibidem.
} 
Większym wrogiem (bo „tchórzem” i „zdrajcą”) staje się wtedy nie obóz przeciwny, lecz „defetysta” i „kapitulant” we własnych szeregach. Okrucieństwo kary dla niego jest porównywalne z tym okazywanym wrogowi zewnętrznemu:

Często pobity sam pokłada jeszcze nadzieje w przypadku, wbrew własnemu przekonaniu wierzy w siłę opatrzności, że szczęście nagle się odwróci. Mimo iż wojna dawno już została rozstrzygnięta, to najdrobniejsze zwycięstwo odnotowane zostaje jako przełom ku lepszemu. Szaleńczą odwagą próbuje się ratować to, co da się jeszcze uratować: towarzyszy broni, rodzinę, własną skórę, wreszcie - honor. [...] Realność porażki nie jest przyjmowana do wiadomości, bezsilność oblekana jest w blask sensu, upadek urasta do rangi fatum ${ }^{34}$.

Strona przegrywająca (jednostronnie „na kolanach”), a nawet obydwie strony kontynuujące walkę w stanie agonalnym niejako sakralizują swoją potencjalną zagładę.

Tę obustronną mękę przedłuża zarówno przedwczesny triumf zwycięzców, który daje okazję do dotkliwych ukąszeń i już niepotrzebnych, możliwych do uniknięcia strat, jak i upojenie zwycięstwem dokonanym, które prowokuje, wręcz wymusza - aktami gwałtu, wandalizmu, profanacji — zrywy do walki już pokonanych, nawet po kapitulacji.

\section{Ekstremalizacja walki (wojny)}

Zrekonstruujmy teraz schemat takiej spirali nierozwiązywalnego konfliktu.

\section{Zadany cios, szkoda, napaść wymaga odparcia.}

To jednak znaczy: nie tylko obrony, lecz i kontrataku, a także „ukarania” rzeczywistego czy domniemanego agresora - a więc odwetu. Do odwetu skłania nie tylko siła reaktywnych emocji, ale również na wpół racjonalna kalkulacja. Napaść nie może pozostać bezkarna, gdyż to mogłoby stanowić zachętę do jej powtórzenia przez ten sam podmiot lub inne, rezygnacja $\mathrm{z}$ odwetu nie byłaby bowiem odebrana jako wielkoduszność, lecz poczytana za oznakę słabości. Nawet w przypadku „ataku komara na słonia” od tej reguły nie ma wyjątku, ponieważ wtedy chodzi o wiarygodność i bezpieczeństwo tego „słonia” (przykład: amerykańska „wojna z terroryzmem” po zamachu na Manhattanie).

\section{Z kolei odwet wymaga oczywiście odwetu.}

Cudza odpowiedź na moją agresję lub kontrataki karne i prewencyjne „wymaga” dalszego zastosowania siły. Zarówno obiektywnie - gdyż tylko ja sam mogę zadbać o własne bezpieczeństwo, nie zadba o nie ten, kogo ja zaatakowałem - jak i subiektywnie, ponieważ zwykle uznajemy cudzy rewanż za niewspółmierny. Nawet kiedy wiemy, że zasłużyliśmy na odpowiedź w postaci jakiegoś uderzenia, uważamy ją za przesadną, krzywdzącą itd. Nastawienie takie jest podobne po obu stronach i odwzajemniane. Toteż wymiana - licytacja - ciosów się powtarza. Uruchomiony zostaje ciąg (łańcuch) prowokacji inicjatywnych, reaktywnych i zwrotnych, tudzież lawinowych, wielostopniowych i kumulatywnych ${ }^{35}$.

\footnotetext{
34 Ibidem, s. 151-152.

35 Por. typologię prowokacji w monografii: M. Karwat, Teoria prowokacji. Analiza politologiczna, Warszawa 2007.
} 


\section{Pęcznieje ładunek nieufności oraz rachunek krzywd, urazów, i nienawiści.}

Nie ma tu znaczenia, kto pierwszy zaczął (jeśli rzeczywiście początkiem konfliktu był atak jednostronny, a nie obustronny, wzajemny, i jeśli nawet można obiektywnie ustalić, kto był tym pierwszym). Istotne jest, że każdego boli i oburza jego strata, cierpienie i krzywda, a nie dolegliwości wroga. Te drugie, jeśli nas interesują, to na zasadzie, że „należy mu się" i że polepszają naszą sytuację. Z tym nastawieniem i kumulacją wrogości trudno jest o gotowość do dialogu, o minimalny choćby kredyt zaufania niezbędny do bezpośrednich rokowań lub cudzej mediacji.

\section{Strony konfliktu stają się zakładnikami, a właściwie więźniami swojej tradycji walki.}

Dziedziczą i kultywują wrogość, której bezpośrednie powody być może są już tylko odległym wspomnieniem, reliktem lub anachronizmem (na podobnej zasadzie, jak to jest $\mathrm{w}$ imperatywie zemsty rodowej, której kontynuacja jest sprawdzianem honoru i przynależności). Jednak nie są w stanie tego przezwyciężyć na zasadzie zdroworozsądkowej (że konflikt się dezaktualizuje, trwa jedynie siłą inercji), gdyż reprodukcja i kultywowanie konfliktu stają się rytuałem potwierdzenia grupowej, wspólnotowej tożsamości ${ }^{36}$. A przy tym konflikt staje się czynnikiem więziotwórczym, sprzyja konsolidacji grupy, determinuje jej wewnętrzną organizację — paradoksalnie więc spełnia rolę pozytywną, czyli konstytutywną dla wspólnoty i regulacyjną w jej życiu wewnętrznym ${ }^{37}$.

Logika działań wojennych wymusza „pójście na całość”, dążenie do maksymalizacji szkód po stronie wroga.

Jest tak nie tylko wtedy, gdy dana strona kieruje się celami zaborczymi, ekspansjonistycznymi i eksploatatorskimi, ale również wtedy, gdy ma to służyć głównie lub jedynie profilaktyce, asekuracji (np. w wojnie „prewencyjnej”). Jednak odpowiedzią drugiej strony na maksymalizację agresji tym bardziej nie może być umiar, powściągliwość. Reakcja obiektywnie musi być co najmniej współmierna do zagrożenia i szkód, sukces wydaje się zaś adwersarzom bardziej prawdopodobny nie pod warunkiem osiągnięcia i utrzymania równowagi stron, lecz pod warunkiem uzyskania przewagi jednej z nich ${ }^{38}$. W rezultacie jednak to nie podmioty - strony konfliktu — rządzą własną siłą, lecz — pod wpływem emocji i emocjonalnie stymulowanej stronniczości, tendencyjności ${ }^{39}$ - siła, przemoc, konflikt rządzą nimi. Nad rozsądkiem i pragmatyzmem przeważają negatywne emocje (mieszanka strachu, wrogości i mściwości) ${ }^{40}$. Również same w sobie reguły gry w rywalizacji i walce wymuszają preferencje dla determinacji w próbie sił, a nie dla umiaru, samoograniczenia ${ }^{41}$. W rezultacie reakcja na cudze zamachy staje się właśnie niewspół-

36 Por. I. Čolović, Polityka symboli. Eseje o antropologii politycznej, Kraków 2001; idem, Bałkany - terror kultury, Wołowiec 2007.

37 Zob. na ten temat: L.A. Coser, Funkcje konfliktu społecznego, Kraków 2009.

38 Por. N. Klatka, Konflikt i gra, Warszawa 1971.

39 Por. A. Golec, Konflikt polityczny: myślenie i emocje, Warszawa 2002.

40 Spektrum emocji negatywnych przedstawione jest w pracy: Z. Zaleski, Od zawiści do zemsty. Społeczna psychologia kłopotliwych emocji, Warszawa 1998.

${ }^{41}$ Por. J. Butler, Ramy wojny. Kiedy życie godne jest opłakiwania?, Warszawa 2011; R. Caillois, Gry i ludzie, Warszawa 1997; Ch. Mouffe, Agonistyka. Polityczne myślenie o świecie, Warszawa 2015; P. Pawełczyk, 
mierna - z powodu przewrażliwienia na własne szkody, a niewrażliwości na cudze, i na zasadzie działania „na zapas”.

Jednocześnie z takimi koniecznościami pragmatycznymi dochodzą do głosu względy prestiżowe.

Licytacja siłą i szkodami zaczyna być traktowana jako wyraz i dowód własnej słuszności, wyższości nad wrogiem (intelektualnej, moralnej, technicznej), jako sprawdzian własnej sprawności tudzież pryncypialności, wierności itd. W tej atmosferze niełatwo może się pojawić i przebić jakakolwiek myśl o odwrocie, remisie, zawieszeniu broni — nawet gdyby w przebiegu walki i po analizie pierwszych kosztów i strat stała się widoczna problematyczność zwycięstwa, gdyby już kiełkowały wątpliwości co do sensu tej konfrontacji i własnych wyrzeczeń.

Strona, która doświadcza pierwszych owoców swej przewagi (choćby chwilowej, jeszcze ostatecznie nieprzesądzonej), poznaje przedsmak prawdopodobnego zwycięstwa, toteż ulega swoistemu samoupojeniu, choć może ono być przedwczesne i spowodować odwrócenie układu sił.

To sprawia, że nawet mając przewage przytłaczającą i wystarczającą do zapewnienia sobie własnego bezpieczeństwa, ochrony stanu posiadania, a nawet nowych korzyści, nie wykazuje jednak umiaru w nękaniu i upokarzaniu swego wroga. Może w tej pysze przekroczyć granicę i przeliczyć się. Wróg niemal już pokonany, lecz przyciśnięty do muru, sprowokowany do determinacji, może dopiero teraz okazać się nadspodziewanie niebezpieczny.

Błędne koło obstrukcji i autodestrukcji.

Jeśli konfrontacja okazuje się nierozstrzygalna (w każdym razie w jakiejś bliskiej perspektywie), natomiast widoczna staje się daremność dotychczasowych strat i następnych wysiłków, a także wątpliwe zdaje się utrzymanie dotychczasowych korzyści w przypadku kontynuacji wojny, a nawet w przypadku, gdy obu stron niemal jednakowo nie stać na to, by walczyć dalej, to jednak nadal szanse na przerwanie tej wojny są znikome.

\section{Dlaczego?}

Po pierwsze, ze względu na ryzyko nieadekwatnej reakcji wroga na naszą gotowość do zaniechania walki (może go to zachęcić do wzmożenia ataku).

Po drugie, ze względu na nieunikniony opór we własnych szeregach.

Strona gotowa do gestów dobrej woli czy realizmu (lub też obydwie strony gotowe do poszukiwania modus vivendi) obawia się, niezupełnie nieracjonalnie, że przez drugą stronę będzie to odebrane jako oznaka słabości, a w każdym razie nie chce być „pierwszą naiwną”.

W tym drugim kontekście: podmiot „trzeźwiejący” obawia się, że nawet jeśli wróg docenia jego siłę, to spróbuje wykorzystać ostatnią okazję, aby tę siłę zmniejszyć, nadużywając tego „rozluźnienia uścisku” i posuwając się do faktów dokonanych, które tym razem zmienią układ sił na jego korzyść. Mamy wtedy błędne koło: nawet jeśli „do tanga trzeba dwojga" i obie strony chcą tego samego (wyjścia z impasu), to jednak nie postę-

Socjotechniczne aspekty gry politycznej, Poznań 2000; D. Tannen, Cywilizacja kłótni. Jak powstrzymać amerykańską wojnę na słowa, Poznań 2003. 
pują solidarnie czy lojalnie, lecz raczej wedle reguły „i chciałabym, i boję się" lub z nastawieniem, kto kogo przechytrzy w negocjacjach.

Wreszcie, gdyby nawet lider jednej ze stron prowadzącej wojnę uznał przewidywalność, a nawet pewną spolegliwość swojego odpowiednika po przeciwnej stronie, nie może być pewny, czy tamten ma wystarczające pełnomocnictwa lub wystarczające przyzwolenie i poparcie, czy będzie w stanie wyegzekwować respektowanie porozumienia we własnych szeregach.

Jednocześnie również jemu grozi opór, nawet bunt ze strony własnych zwolenników i podwładnych - oskarżenia o ugodowość, „mięczakowatość”, naiwność lub o zdradę (kolaborację) w zamian za własne korzyści.

Nawet gdyby do tych zachowań nie skłaniały oponentów, przeciwników zawieszenia broni lub porozumienia ich własne, osobiste ambicje i okazja do przejęcia władzy, to i tak silniejsza jest obiektywna logika konfliktu, polegająca na tym, że w obliczu konfrontacji z wrogami i obcymi następuje nieuniknione zwieranie szeregów, dyscyplinowanie współbojowników i współwyznawców, sekciarska podejrzliwość - większa nawet wobec własnych "niepewnych" niż wobec obcych.

Z kolei, jeśli lider taki - dla zyskania wiarygodności w oczach partnerów trudnych rokowań - usiłuje wykazać twardą rękę wobec swoich własnych „frondystów”, tym bardziej naraża się na oskarżenia, że ta jego „nadgorliwość” jest znamieniem kapitulacji lub zdrady albo agenturalności; tym bardziej narażony jest na akty dywersji, ciosy $\mathrm{w}$ plecy, demonstracyjne akty nieposłuszeństwa, a nawet na karę i zemstę „nieugiętych”.

To w oczywisty sposób opóźnia, paraliżuje lub przekreśla i unieważnia jego działania pojednawcze czy próby przerzucenia licytacji z płaszczyzny siłowej na płaszczyznę dyplomatyczną.

W rezultacie przeciwnikom „zdrady” udaje się podważyć wiarygodność lidera „kapitulanta”.

Tak czy inaczej, staje się on niewiarygodny: gdyż albo okazuje się zbyt słaby, aby zagwarantować respektowanie rozejmu, dotrzymanie porozumień pokojowych, albo też wskutek dywersji we własnym obozie posądzany i oskarżany jest o krętactwo, hipokryzję, grę nierzetelną. Zatem bez względu na jego intencje powstaje i utrwala się wrażenie, że nie ma sensu z nim prowadzić rozmów, a nawet rodzi się nastawienie, by to $\mathrm{w}$ nim widzieć główną przeszkodę na drodze do porozumienia. Z perspektywy minionych lat w tych kategoriach można by interpretować beznadziejne uwikłanie zarówno Arafata, jak i polityków izraelskich podejmujących próbę dialogu i zawierających pokojowe porozumienia ze stroną palestyńską.

\section{Podsumowanie}

Model „spirali przemocy w konfliktach” jest na tyle sugestywny, że podkreślić trzeba nie tylko to, iż odnosi się do konfliktów antagonistycznych, nie wszelkich, ale również to, że ma charakter idealizacyjny. I wreszcie to, że materializuje się on w sytuacji, gdy do- 
szło do bezpośredniego zwarcia (wojny rozumianej dosłownie, działań terrorystycznych lub partyzanckich i przeciwdziałań, względnie wojny propagandowej ze skrajnym natężeniem przemocy rytualno-symbolicznej). Inaczej rzecz się przedstawia w konfliktach rozgrywanych na zasadzie potencjalizacji ${ }^{42}$, w tym wypadku - w postaci wzajemnego szachowania się stron możliwymi zagrożeniami. Historycznym przykładem tego jest „kontrolowany wyścig zbrojeń”, gdy napięcia i incydenty lub selektywne wypady nie wykraczały poza regułę „pokojowego współistnienia” — ze względu na groźbę wspólnej zagłady.

\section{Bibliografia}

Adler W., Wojna państwa Rose, Wydawnictwo Zysk i S-ka, Poznań 2002 [powieść; sfilmowana w reż. D.M. de Vito].

Bieleń S., Negocjacje w stosunkach międzynarodowych, Oficyna Wydawnicza ASPRA-JR, Warszawa 2013.

Butler J., Ramy wojny. Kiedy życie godne jest opłakiwania?, Instytut Wydawniczy Książka i Prasa, Warszawa 2011.

Caillois R., Gry i ludzie, Volumen, Warszawa 1997.

Chełpa S., Witkowski T., Psychologia konfliktów. Sposoby radzenia sobie ze sporami, Oficyna Wydawnicza Unus, Wrocław 1999.

Čolović I., Bałkany - terror kultury. Wybór esejów, Wydawnictwo Czarne, Wołowiec 2007.

Čolović I., Polityka symboli. Eseje o antropologii politycznej, Towarzystwo Autorów i Wydawców Prac Naukowych Universitas, Kraków 2001.

Coser L.A., Funkcje konfliktu społecznego, Zakład Wydawniczy „Nomos”, Kraków 2009.

Fromm E., Anatomia ludzkiej destrukcyjności, Dom Wydawniczy Rebis, Poznań 1999.

Golec A., Konflikt polityczny: myślenie i emocje, Wydawnictwo Akademickie Dialog, Warszawa 2002.

Grzegorczyk A., Wszyscy chcemy być ważni i niezależni, [w:] Gwatt i perswazja. Antologia publicystyki z lat 1981-1983, red. J. Adamski, Państwowy Instytut Wydawniczy, Warszawa 1983.

Gwatt i perswazja. Antologia publicystyki z lat 1981-1983, red. J. Adamski, Państwowy Instytut Wydawniczy, Warszawa 1983.

Karolczuk E., O wrogu. Szkice filozoficzno-historyczne, Instytut Wydawniczy Książka i Prasa, Warszawa 2010. Karwat M., Akredytacja w życiu społecznym i politycznym, Oficyna Wydawnicza ASPRA-JR, Warszawa 2009. Karwat M., O złośliwej dyskredytacji. Manipulowanie wizerunkiem przeciwnika, PWN, Warszawa 2006.

Karwat M., Podstawy socjotechniki. Dla politologów, polityków i nie tylko, Difin SA, Warszawa 2014.

Karwat M., Teoria prowokacji. Analiza politologiczna, PWN, Warszawa 2007.

Kępiński A., Psychopatologia nerwic, Państwowy Zakład Wydawnictw Lekarskich, Warszawa 1986.

Klatka N., Konflikt i gra, Wydawnictwo MON, Warszawa 1971.

Kotarbiński T., Abecadło praktyczności, Wiedza Powszechna, Warszawa 1972.

Kotarbiński T., Dzieła wszystkie. Prakseologia, część I, Ossolineum, Wrocław 1999.

Kotarbiński T., Traktat o dobrej robocie, Ossolineum, Wrocław 1975.

Łukaszewski W., Szanse rozwoju osobowości, Książka i Wiedza, Warszawa 1984.

Mazur M., Cybernetyka i charakter, Państwowy Instytut Wydawniczy, Warszawa 1978.

Mouffe Ch., Agonistyka. Polityczne myślenie o świecie, Wydawnictwo Krytyki Politycznej, Warszawa 2015.

42 Zasadę potencjalizacji (oddziaływania na innych poprzez taką możliwo ść własnego działania, która ogranicza swobodę działania innych lub stwarza pewne konieczności, wymusza ich reakcje asekuracyjne, antycypacyjne lub przystosowawcze) analizuje T. Kotarbiński w swych pismach z zakresu teorii walki. Zob. T. Kotarbiński, Dzieła wszystkie. Prakseologia, część I, Wrocław 1999. 
Noelle-Neumann E., Spirala milczenia. Opinia publiczna - nasza skóra społeczna, Wydawnictwo Zysk i S-ka, Poznań 2004.

Oz A., Czarownik swojego plemienia. Eseje, Prószyński i S-ka, Warszawa 2007.

Oz A., Jak uleczyć fanatyka, Prószyński Media, Warszawa 2010.

Pawełczyk P., Socjotechniczne aspekty gry politycznej, Wydawnictwo Naukowe UAM, Poznań 2000.

Reykowski J., Logika walki, Książka i Wiedza, Warszawa 1984.

Reza Y., Bóg mordu, Wydawnictwo Sonia Draga, Katowice 2012 [sztuka teatralna; ekranizacja: Rzeź w reż. R. Polańskiego].

Rokita J., Pięć wizji wroga, „Horyzonty polityki” 6, 2015, nr 15.

Rozwiązywanie konfliktów. Teoria i praktyka, red. M. Deutsch, P.T. Coleman, Wydawnictwo Uniwersytetu Jagiellońskiego, Kraków 2005.

Rudniański J., Kompromis i walka. Sprawność i etyka kooperacji pozytywnej i negatywnej w gęstym otoczeniu społecznym, Instytut Wydawniczy Pax, Warszawa 1989.

Runciman D., Political Hipocrisy. The Mask of Power, from Hobbes to Orwell and Beyond, Princeton University Press, Princeton 2008.

Sofsky W., Traktat o przemocy, Wydawnictwo Dolnośląskie, Wrocław 1999.

Tannen D., Cywilizacja kłótni. Jak powstrzymać amerykańską wojnę na słowa, Wydawnictwo Zysk i S-ka, Poznań 2003.

Vargas Llosa M., Izrael-Palestyna. Pokój czy święta wojna, Świat Książki, Warszawa 2007.

Zaleski Z., Od zawiści do zemsty. Społeczna psychologia kłopotliwych emocji, Wydawnictwo Akademickie „Żak”, Warszawa 1998.

Zimbardo P., Efekt Lucyfera. Dlaczego dobrzy ludzie czyniq zło?, Wydawnictwo Naukowe PWN, Warszawa 2008.

Ziółkowski J., Syndrom oblężonej twierdzy jako mechanizm socjotechniczny, [w:] Socjotechnika lęku w polityce, red. F. Pierzchalski, J. Golinowski, Wydawnictwo Uniwersytetu Kazimierza Wielkiego, Bydgoszcz 2016.

Ziółkowski J., Wrogość jako paradoks demokracji, [w:] Antynomie i paradoksy wspótczesnej demokracji, red. M. Tobiasz, DW Elipsa, Warszawa 2016.

Ziółkowski J., Wrogość w stosunkach politycznych. Modelowa analiza funkcjonalna, DW Elipsa, Warszawa 2013.

Ziółkowski J., Zarzadzanie syndromem oblężonej twierdzy w demokracji liberalnej, [w:] Wplyw i władza w systemie demokratycznym, red. idem, Warszawa 2016 (= „Studia Politologiczne” 41).

\section{The spiral of violence in the social conflicts}

Keywords: antagonism, vicious circle, antagonistic conflict, escalation, violence, spiral of violence

\section{Summary}

In the antagonistic conflicts between sides with the equalized potential it is possible such a situation that none of the sides is able to win, nor to cut off the fight although their own forces are running out and thus increases the threat of self-destruction. This endless exchange of blows is escalating in time and causing more destruction and damage than profits. The unilateral initiative of armistice is impossible, because both fighters are afraid that it may be viewed as a symptom of weakness and incentive to intensify attacks. In their own ranks striving for agreement with the adversary may be condemned and obstructed as a betrayal. Then the vicious circle of the insoluble struggle sets the spiral of violence. 